Article

\title{
A Novel Iminosugar UV-12 with Activity against the Diverse Viruses Influenza and Dengue (Novel Iminosugar Antiviral for Influenza and Dengue)
}

Kelly L. Warfield ${ }^{1, *}$, Emily Plummer ${ }^{2}$, Dominic S. Alonzi ${ }^{3}$, Gary W. Wolfe ${ }^{4}$, Aruna Sampath ${ }^{1}$, Tam Nguyen ${ }^{5}$, Terry D. Butters ${ }^{3}$, Sven G. Enterlein ${ }^{6}$, Eric J. Stavale ${ }^{6}$, Sujan Shresta ${ }^{2}$ and Urban Ramstedt ${ }^{1}$

1 Unither Virology LLC, Silver Spring, MD 20910, USA;

E-Mails: asampath@unithervirology.com (A.S.); urban_ramstedt@yahoo.com (U.R.)

2 La Jolla Institute for Allergy and Immunology, La Jolla, CA 92037, USA;

E-Mails: eplummer@liai.org (E.P.); sujan@lji.org (S.S.)

3 Oxford Glycobiology Institute, Oxford OX1 3QU, UK, E-Mails: dominic.alonzi@bioch.ox.ac.uk (D.S.A.); terry.butters@btinternet.com (T.D.B.)

4 Gary Wolfe Toxicology, Herndon, VA 20170, USA; E-Mail: gary@gwtox.com

5 Tam Nguyen LLC, Gaithersburg, MD 20879, USA; E-Mail: tam.3.nguyen@gmail.com (T.N.)

6 Integrated Biotherapeutics, Gaithersburg, MD 20878, USA;

E-Mails: sven@integratedbiotherapeutics.com (S.G.E.); eric@integratedbiotherapeutics.com (E.J.S.)

* Author to whom correspondence should be addressed; E-Mail: kwarfield@unithervirology.com; Tel.: +1-202-552-0545; Fax: +1-202-552-0539.

Academic Editor: Curt Hagedorn

Received: 16 March 2015 / Accepted: 7 May 2015 / Published: 13 May 2015

\begin{abstract}
Iminosugars are capable of targeting the life cycles of multiple viruses by blocking host endoplasmic reticulum $\alpha$-glucosidase enzymes that are required for competent replication of a variety of enveloped, glycosylated viruses. Iminosugars as a class are approved for use in humans with diseases such as diabetes and Gaucher's disease, providing evidence for safety of this class of compounds. The in vitro antiviral activity of iminosugars has been described in several publications with a subset of these demonstrating in vivo activity against flaviviruses, herpesviruses, retroviruses and filoviruses. Although there is compelling non-clinical in vivo evidence of antiviral efficacy, the efficacy of iminosugars as antivirals has yet to be demonstrated in humans. In the current study, we report a novel
\end{abstract}


iminosugar, UV-12, which has efficacy against dengue and influenza in mouse models. UV-12 exhibits drug-like properties including oral bioavailability and good safety profile in mice and guinea pigs. UV-12 is an example of an iminosugar with activity against multiple virus families that should be investigated in further safety and efficacy studies and demonstrates potential value of this drug class as antiviral therapeutics.

Keywords: glucosidase; glycosylation; Flaviviridae; flavivirus; Orthomyxoviridae; orthomyxovirus; mouse

\section{Introduction}

Iminosugars that are glucomimetics function as competitive endoplasmic reticulum (ER) $\alpha$-glucosidase inhibitors and have antiviral activity through a host based mechanism. For these reasons, iminosugars offer an attractive avenue for developing broad spectrum antiviral therapies [1,2]. Viruses that require use of the host-cell glycosylation pathway for replication are susceptible to targeting by the iminosugar class of drugs. Blocking this glycosylation pathway via inhibition of the $\alpha$-glucosidase enzymes in the ER leads to the misfolding of viral glycoproteins that are subsequently sent to the proteasome for degradation and elimination or to the production of defective daughter virions comprised of misfolded proteins [2-5]. Key data validating ER $\alpha$-glucosidases as an antiviral target are provided by a recent publication by Sadat et al. [6]. The authors identified two siblings with a spectrum of developmental abnormalities, but with no history of viral disease in spite of significant hypogammaglobulinemia. The underlying genetic defect is knock-out of the ER $\alpha$-glucosidase I, a target enzyme for our inhibitor program. Neither of the siblings were able to generate appropriate immune responses to live viral vaccines including measles, mumps, rubella, and varicella and cells from these subjects are deficient in uptake and maturation of multiple divergent viruses including HIV and influenza. This report supports that pharmacological inhibition of the ER $\alpha$-glucosidases should result in broad-spectrum antiviral effects.

Our host-based, broad-spectrum antiviral drug platform is based on iminosugar analogs of N-butyl-deoxynojirimycin (NB-DNJ or miglustat), which is approved for use in humans. NB-DNJ is an orally available, relatively inexpensive to manufacture drug that is safe and is used for treatment of Gaucher's disease [7]. NB-DNJ has also been shown to exhibit broad-spectrum antiviral activity in vitro against viruses including DENV, HCV, and HIV but requires concentrations $(>30 \mu \mathrm{M})$ that are unreasonable to achieve in vivo [3]. Another well described iminosugar, castanospermine, demonstrates more potent antiviral activities against a range of viruses including flaviviruses, herpesviruses, influenza virus (INFV) and retroviruses [8-12]. Additional validation of this approach is provided in recent publications describing iminosugar ER $\alpha$-glucosidase inhibitors with efficacy against diverse viruses including flaviviruses, influenza virus and filoviruses in mice [13-18].

By targeting a set of host enzymes, we expect to overcome liabilities of directly acting antivirals. Using iminosugars to target the host ER $\alpha$-glucosidases that are critical for replication of a wide variety of viral families having properties of glycosylated structural proteins and enveloped virions, it is expected that a single drug could be used for multiple acute viral infections. Use of a host-targeted antiviral is not expected to result in selection of drug-resistant viral strains since pressure is not 
directly exerted on the virus itself during replication [19]. Here we describe a novel iminosugar (2R,3R,4R,5S)-2-(hydroxymethyl)-1-(8-(tetrahydrofuran)-2-yl)octyl)piperidine-3,4,5-triol that we named UV-12 (structure shown in Figure 1), having strong drug-like properties and in vivo activity against the divergent dengue (DENV) and influenza viruses.

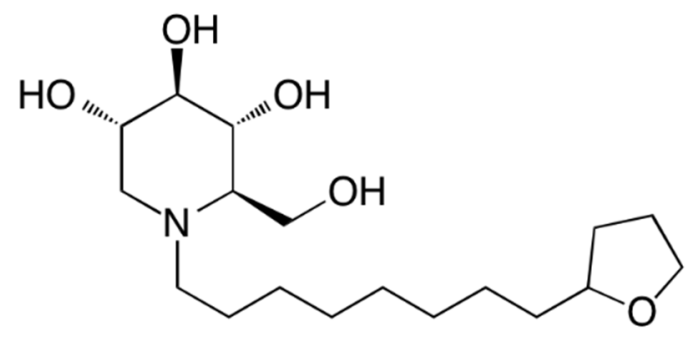

Figure 1. Structure of the iminosugar UV-12.

\section{Materials and Methods}

\subsection{Inhibition of $\alpha$-Glucosidases}

\subsubsection{Purified Enzyme Inhibition}

The assays for ER $\alpha$-glucosidases I and II [20] used enzymes purified from rat liver as previously described [21,22]. Oligosaccharide substrates $\operatorname{Glc}_{(1-3)} \operatorname{Man}_{(4-7)} \operatorname{GlcNAc}_{(1-2)}$ were isolated from cultured cells treated with an $\alpha$-glucosidase inhibitor, NB-DNJ, and purified by normal phase high-performance liquid chromatography (NP-HPLC) following fluorescent labeling [20]. Enzyme was incubated for up to $2 \mathrm{~h}$ with oligosaccharide substrate and UV-12 at various concentrations. The reaction was terminated and the products separated by NP-HPLC. The amount of digestion was measured in comparison to control (no inhibitor) and dose-response data plotted using a four-parameter logistic model (Hill-Slope). The 50\% inhibitory concentration ( $\mathrm{IC}_{50}$ ) value was calculated for $\alpha$-glucosidase I (Glc3 substrate) and $\alpha$-glucosidase II (Glc2 substrate and Glc1 substrate).

\subsubsection{Cellular Inhibition of Endoplasmic Reticulum $\alpha$-Glucosidase Activity Using Free}

Oligosaccharide (FOS) Assay

We have previously reported a cell-based assay for evaluation of effects of iminosugars on ER $\alpha$-glucosidases [20]. Briefly, human (HL60) cells were cultured to a high density $\left(1 \times 10^{7} \mathrm{cells} / \mathrm{mL}\right)$ in the presence of UV-12 in fresh medium containing at multiple concentrations for $24 \mathrm{~h}$ before cells were harvested, washed and extracted for free oligosaccharides (FOS). The cells were seeded at a lower density to achieve a high density at the end of the incubation period. Following cell culture, the medium was removed and the cells were washed three times with PBS by centrifugation. Washed cells were stored at $-20{ }^{\circ} \mathrm{C}$ for a short time before thawing and Dounce homogenization in water. The maximum recovery of FOS was performed using the following conditions. The homogenate from $0.1-0.2 \mathrm{mg}$ protein was desalted and deproteinated by passage through a mixed-bed ion-exchange column $[0.2 \mathrm{~mL}$ of AG50W-X12 ( $\left.\mathrm{H}^{+}, 100-200 \mathrm{mesh}\right)$ over $0.4 \mathrm{~mL}$ of AG3-X4 $\left.\left(\mathrm{OH}^{-}, 100-200 \mathrm{mesh}\right)\right]$, pre-equilibrated with water $(5 \times 1 \mathrm{~mL})$. The homogenate was added to the column which was washed with $4 \times 1 \mathrm{~mL}$ of 
water, and the eluate collected. The extracted and purified FOS were then dried under vacuum or by lyophilizing. The FOS were labelled with 2-AA and purified using DPA-6S columns as described previously [20]. Labelled oligosaccharides in $50 \mathrm{mM}$ Tris/ $\mathrm{HCl}$ buffer, $\mathrm{pH} 7.2$, were purified using a ConA (Concanavalin A)-Sepharose 4B column (100 $\mu \mathrm{L}$ packed resin). The column was pre-equilibrated with $2 \AA \sim 1 \mathrm{~mL}$ of water followed by sequential $1 \mathrm{~mL}$ washes of $1 \mathrm{mM} \mathrm{MgCl}_{2}, 1 \mathrm{mM} \mathrm{CaCl}$, $1 \mathrm{mM} \mathrm{MnCl} 2$ and $2 \AA \sim 1 \mathrm{~mL}$ of $50 \mathrm{mM}$ Tris/HCl buffer, $\mathrm{pH}$ 7.2. The sample was added and allowed to pass through the column before washing with $2 \AA \sim 1 \mathrm{~mL}$ of $50 \mathrm{mM}$ Tris/HCl buffer, $\mathrm{pH}$ 7.2. The ConA-bound FOS were then eluted with $2 \times 1 \mathrm{~mL}$ of hot $\left(70{ }^{\circ} \mathrm{C}\right) 0.5 \mathrm{M}$ methyl $\alpha$-D-mannopyranoside in $50 \mathrm{mM}$ Tris/ $\mathrm{HCl}$ buffer, pH 7.2. The purified and fluorescently labelled FOS were separated by NP-HPLC [20].

Free glucosylated oligosaccharides were measured as a biochemical product of ER $\alpha$-glucosidase I and II inhibition. The peak areas of glucosylated FOS corresponding to Glc $\mathrm{Man}_{4} \mathrm{GlcNAc}_{1}$ and $\mathrm{Glc}_{3} \mathrm{Man}_{5} \mathrm{GlcNAc}_{1}$, and in some instances $\mathrm{Glc}_{3} \mathrm{Man}_{7} \mathrm{GlcNAc}_{2}$, were measured and used to determine the relative amount of $\alpha$-glucosidase I and II inhibition in cells.

\subsubsection{Cellular Half-Life of Endoplasmic Reticulum $\alpha$-glucosidase I Blockage}

MDBK cells were treated with $100 \mu \mathrm{M} \mathrm{UV-12}$ for $24 \mathrm{~h}$ to generate Glc $3 \mathrm{Man}_{7} \mathrm{GlcNAc}_{2}$ [23]. UV12 was removed and cells cultured for $96 \mathrm{~h}$. The level of Glc3Man7GlcNAc2 was monitored using the FOS assay (Section 2.1.2) every $24 \mathrm{~h}$. Half-life was determined as the time when the level of $\mathrm{Glc}_{3} \mathrm{Man}_{7} \mathrm{GlcNAc}_{2}$ declined to $50 \%$ of the initial accumulation.

\subsection{Cytotoxicity and in Vitro Antiviral Activity}

\subsubsection{Cytotoxicity}

The cytotoxicity of UV-12 in Madin-Darby Canine Kidney (MDCK) and Vero cells was determined based on the manufacturer's instructions using a commercially available kit (CellTiter-Glo Luminescent Cell Viability Assay (Promega, Madison, WI, USA)). UV-12 was tested at 6 concentrations starting at $500 \mu \mathrm{M}$ with subsequent two-fold dilutions. Cytotoxicity was measured after 5 days. The $50 \%$ cellular cytotoxicity $\left(\mathrm{CC}_{50}\right)$ value was determined by comparing the compound-treated samples with vehicle-only treated cells set as $100 \%$ survival and no cells set as $0 \%$ survival.

\subsubsection{In Vitro Antiviral Activity}

The in vitro antiviral activity of UV-12 was tested using a virus yield-plaque assay or tissue culture infectious dose (TCID) format to determine the reduction in titer of virus after growth in the presence of multiple concentrations of compound. Viruses used for these studies included DENV (serotype 2, New Guinea C isolate propagated in Vero cells), INFV (mouse-adapted A/Texas/36/91 (H1N1) propagated in MDCK cells) or Venezuelan Equine Encephalitis virus (VEEV, TC-83 vaccine strain propagated in Vero cells). UV-12 was tested at 8 concentrations starting at $250 \mu \mathrm{M}$ with subsequent two-fold dilutions in Vero (DENV and VEEV) or MDCK (INFV) cells. UV-12 was added to cells $1 \mathrm{~h}$ before infection, DENV, INFV or VEEV was used for infection at an MOI of $0.01,0.01$ or 0.1 , respectively. Supernatants were harvested and clarified of cell debris after 5 days for DENV and INFV or 3 days for VEEV and analyzed for virus content using an immunoplaque (DENV), TCID (INFV) or plaque (VEEV) assay. 
A four-parameter logistic curve was used to generate $50 \%$ inhibitory concentration $\left(\mathrm{IC}_{50}\right)$ was calculated using XLFit equation 205 based on percent reduction of virus yield compared to the virus titer in media-treated cells.

\subsection{In Vitro Absorption-Distribution-Metabolism-Elimination (ADME) Studies}

UV-12 was tested for drug-likeness using a panel of standard assays including ADME profiling for plasma protein binding, metabolic stability in human liver microsomes, permeability/efflux, solubility, Cytochrome P450 (CYP) inhibition, and hERG binding. These assays were performed by Advinus Therapeutics Limited (Bangalore, India).

\subsubsection{Protein Binding Studies in Mouse, Rat, Dog and Human Plasma}

Protein binding of UV-12 was determined in mouse, rat, dog and human plasma. Each plasma sample was spiked with a single concentration $(10 \mu \mathrm{M})$ of compound, incubated for $6 \mathrm{~h}$, dialyzed against buffer and liquid chromatography tandem mass spectrometry (LC-MS/MS) was used to determine the unbound and bound percentages of UV-12 to the plasma proteins.

\subsubsection{Metabolic Stability in Mouse, Rat, Dog and Human Liver Microsomes}

The in vitro metabolic stability of UV-12 in mouse, rat, dog and liver microsomes was evaluated at one substrate concentration $(0.5 \mu \mathrm{M})$, one protein concentration $(0.5 \mathrm{mg} / \mathrm{mL})$, and ten time points in duplicate $(0,3,6,9,12,15,18,21,27$ and $30 \mathrm{~min})$. LC-MS/MS was used to monitor the clearance of each compound to calculate the half-life $\left(\mathrm{T}^{1} / 2\right)$.

\subsubsection{Permeability/Efflux Ratio in Caco-2 Cells}

The in vitro apparent permeability of UV-12 at $10 \mu \mathrm{M}$ was determined across a Caco- 2 cell monolayer to assess intestinal transport in both directions (apical to basolateral, A:B, and basolateral to apical, B:A). LC-MS/MS was used to determine the UV-12 concentration.

\subsubsection{Solubility}

Aqueous solubility of the test compounds was be tested in phosphate buffered saline (PBS) at 10, 20, 40, 60, 80 and $100 \mu \mathrm{M}$ with LC-MS/MS as the detection method.

\subsubsection{Inhibition of Cytochrome P450 1A2, 2C9, 2C19, 2D6 and 3A4 Isoenzymes}

The in vitro inhibition of cytochrome P450 (CYP) 1A2, 2C9, 2C19, 2D6 and 3A4 isozymes by UV-12 was evaluated in human liver microsomes by monitoring production of selected metabolites following incubation with probe substrates using LC-MS/MS detection. For each isozyme, a standard CYP-specific probe substrate was incubated along with human liver microsomes and cofactors, and production of selected metabolite was measured. The inhibitory effect of increasing concentrations of $\mathrm{UV}-12$ up to $100 \mu \mathrm{M}$ on the production of the metabolite was determined, and the concentration of inhibitor required for a $50 \%$ reduction in the measured enzyme activity was estimated. 


\subsubsection{Functional hERG Assay}

To test the ability of UV-12 for potential to inhibit the hERG (human ether-a-go-go-related gene) channel, three concentrations (30, 100 and $300 \mu \mathrm{M}$ ) were tested using a standard automated whole-cell patch clamp method using a Chinese Hamster Ovary (CHO) cell line stably transfected with hERG gene [24].

\subsubsection{Ames Test}

UV-12 was tested for mutagenic potential in the miniaturized version of the Ames (mini-Ames) assay using histidine auxotrophic strains of Salmonella typhimurium TA98, TA100 and TA1535 [25]. The bacterial tester strains were exposed to the test item in the presence and absence of metabolic activation system (S-9 fraction prepared from Aroclor 1254 induced rat liver). UV-12 was tested at doses of 1.5, $5,15,50,150,500,1500$ and $5000 \mu \mathrm{g}$ per plate along with DMSO as vehicle control and appropriate positive controls in a direct plate incorporation assay.

\subsection{In Vivo Efficacy Studies}

\subsubsection{UV-12 Preparation and Treatment Regimens}

Mice were treated orally three times daily (TID at eight hour intervals) with UV-12 dissolved in acidified water at $20-100 \mathrm{mg} / \mathrm{kg} /$ dose for 7 (DENV) or 10 days (INFV) starting at $-1 \mathrm{~h}$ relative to infection unless otherwise indicated. UV-12 was delivered in 50 (DENV) or 100 (INFV) $\mu \mathrm{L}$ per dose. Water-only was used as the negative control treatment in all studies delivered with the same regimen as UV-12.

\subsubsection{Health Assessments, Early Endpoints and Oversight}

Weights, health scores and temperatures were monitored and recorded daily for the duration of the study on individual mice. A standard health scoring system from 1-7 was utilized where scores indicated the following: 1 , healthy; 2 , slightly ruffled; 3 , ruffled; 4 , sick; 5 , very sick; 6 , moribund; and 7 , found dead. Mice were sacrificed at a health score greater than or equal to 5 or when a weight loss of $>30 \%$ of their original weight was recorded. Animals were euthanized in accordance with the 2013 American Veterinary Medical Association (AVMA) Guidelines on Euthanasia using carbon dioxide exposure followed by cervical dislocation. All experimental procedures and studies were preapproved and performed according to guidelines set by the Noble Life Sciences Animal Care and Use Committee for influenza virus studies (protocol 10-09-003-IBT) and the La Jolla Institute for Allergy and Immunology Animal Care and Use Committee for studies with dengue virus (protocol AP028-SS1-0612).

\subsubsection{Influenza Efficacy Studies}

Influenza efficacy studies were performed as previously described [18]. Groups of ten 6-8 week-old female BALB/c mice (Charles River Labs) were microchipped (Bio Medic Data Systems) for identification and temperature monitoring at least 3 days prior to infection. Mice were infected with approximately 52 plaque-forming units (PFU) of A/Texas/36/91 (H1N1) diluted in phosphate-buffered saline (PBS) via intranasal administration under light anesthesia with isoflurane. Mice were treated via 
oral gavage with UV-12 at indicated time relative to infection at various concentrations three times daily. After challenge, mice were monitored at least daily for weights, health and survival for a total of 14 days.

\subsubsection{Dengue Efficacy Studies}

The animal model used for this study is AG129 (129/Sv IFN- $\alpha / \beta$ and $-\gamma$ receptor deficient) mice infected with $1 \times 10^{4}$ pfu via IV injection with Dengue 2 (DENV2) strain S221 with antibody dependent enhancement (ADE), which die of TNF- $\alpha$ mediated acute/early death by day 4-5. AG129 mice of both sexes and aged 5-6 weeks at the start of the study were used as the test system for DENV. The AG129 mice were bred and housed under specific pathogen-free conditions at the La Jolla Institute (LJI). Mice were ear-tagged for identification. Generation and preparation of DENV2 strain S221 is described previously [26-29]. One hour before virus infection, $5 \mu \mathrm{g}$ of the monoclonal antibody $2 \mathrm{H} 2$ (anti-prM/M) was administered in $200 \mu \mathrm{L}$ PBS via intraperitoneal injection (IP) to induce the antibody dependent enhancement-mediated DHF/DSS-like disease. The challenge virus, DENV2 S221 was administered in a volume of $200 \mu \mathrm{L}$ (injected virus diluted in PBS $+5 \%$ FCS) via intravenous (IV) tail vein injection with $10^{9} \mathrm{GE}$ (genomic equivalents).

To assess the efficacy of UV-12 against a lethal DENV2 infection, AG129 mice were treated with 20 or $100 \mathrm{mg} / \mathrm{kg}$ of UV-12 orally thrice daily for 7 days starting $1 \mathrm{~h}$ before challenge using the ADE DENV model. Mice were monitored at least daily for health, weight and survival for 10 days total. To assess the efficacy of UV-12 in reducing the viral load and modifying the cytokine responses of mice challenged with dengue virus, UV-12 was administered orally starting at $1 \mathrm{~h}$ before infection and delivered three times daily until the time of sampling at 72 or $96 \mathrm{~h}$ post infection. Viral titers in the serum or liver, spleen, kidney and small intestines were determined by qRT-PCR for each sample from individual animals and the mean with standard deviation are also shown for each group. Serum was separated using serum collection tubes and viral RNA was isolated from serum using Qiagen Viral RNA isolation kits. Brains were removed and immediately stored in RNAlater at $4{ }^{\circ} \mathrm{C}$. Organs were homogenized and total RNA was isolated using Qiagen RNeasy isolation kits. Dengue virus 2 qRT-PCR was performed on all samples, and genomic equivalent (GE) per $\mathrm{ml}$ of serum or in tissue was determined as previously described [28]. Data are shown as log DENV genome equivalents per $\mathrm{mL}$ of serum or as $\log$ DENV genome equivalents per relative $18 \mathrm{~S}\left(\times 10^{4}\right)$ for the tissues analyzed. Serum from control (water) and UV-12 treated animals were also tested for levels of eotaxin, G-CSF, GM-CSF, IFN- $\gamma$, IL-1 $\alpha$, IL-1 $\beta$, IL-2, IL-3, IL-4, IL-5, IL-6, IL-9, IL-10, IL-12 (p40), IL-12 (p70), IL-13, IL-17A, KC, MCP-1 (MCAF), MIP-1 $\alpha$, MIP-1 $\beta$, RANTES and TNF- $\alpha$ (Bio-Plex Pro ${ }^{\text {TM }}$ Mouse Cytokine 23-plex Assay). All samples were analyzed as recommended by the manufacturer (Bio-Rad, Hercules, CA, USA).

\subsubsection{Statistical Analysis}

Survival data was analyzed in GraphPad Prism using log-rank analysis. Cytokine data and viral titer data were analyzed using GraphPad Prism using a two-tailed $t$-test. 


\subsection{In Vivo Pharmacokinetic (PK) and Safety Studies}

\subsubsection{Sample Analysis}

A fit-for-purpose LC-MS/MS method with a lower limit of quantification of 5.10 or $10.01 \mathrm{ng} / \mathrm{mL}$ for mice or guinea pigs, respectively, was used for quantification of UV-12 in plasma samples. The pharmacokinetic parameters of UV-12 were calculated using the non-compartmental analysis tool of WinNonlin ${ }^{\circledR}$ software (Version 5.2, Pharsight Corporation, St. Louis, MO, USA).

\subsubsection{Mouse PK Analysis}

To investigate the bioavailability and PK of UV-12, male Swiss Albino mice ( $n=24$ total) were administered UV-12 via IV injection or oral gavage. Blood samples ( $n=3$ per time point) were collected at 0.083 (only IV), $0.25,0.5,1,2,4,8$ and $16 \mathrm{~h}$ post-dose. At each collection time, approximately $120 \mu \mathrm{L}$ of blood was withdrawn from retro orbital plexus and transferred to pre-labeled microfuge tube containing $200 \mathrm{mM} \mathrm{K}_{2}$-EDTA solution $(20 \mu \mathrm{L}$ per $\mathrm{mL}$ of blood) as anticoagulant. Blood samples were centrifuged at $5000 \mathrm{~g}$ for $5 \mathrm{~min}$ at $4 \pm 2{ }^{\circ} \mathrm{C}$ to separate plasma and stored below $-60{ }^{\circ} \mathrm{C}$ until bioanalysis. These studies were performed at Advinus Therapeutics Limited (Bangalore, India) under approved study numbers N1883 and N1884).

\subsubsection{Guinea Pig Pharmacokinetics and Maximum Tolerated Dose}

To determine the maximum tolerated dose of UV-12 in female Hartley guinea pigs, doses of 20, 40, 60,80 and $100 \mathrm{mg} / \mathrm{kg}$ body weight was administered by the intramuscular route and at the doses of 10 , $20,40,60$ and $80 \mathrm{mg} / \mathrm{kg}$ body weight by the IV route. The oral route was not selected for guinea pig dosing due to difficulties with repeated oral gavage procedures in this species. The different concentrations of UV-12 were administered at an equivolume dose of $2 \mathrm{~mL} / \mathrm{kg}$ bodyweight. The animals ( $n=3$ /group) were observed for clinical signs and mortality and gross necropsy was performed on the dead animals and the animals surviving the observation period of 7 days.

To assess the bioavailability and pharmacokinetic parameters of UV-12 in Hartley guinea pigs, animals were administered a single subcutaneous, intramuscular or IV bolus of 100,100 or $25 \mathrm{mg} / \mathrm{kg}$ body weight of UV-12, respectively. A total of 9 female guinea pigs were used in this study. Blood samples from each guinea pig were collected at pre-dose and at 0.083 (only for IV), 0.25, 0.5, 1 , 2, 4, 8 and $16 \mathrm{~h}$ post-dose. At each time point, approximately $0.5 \mathrm{~mL}$ of blood was withdrawn from jugular vein of the cannulated guinea pig. The blood samples were collected into pre-chilled (at $4{ }^{\circ} \mathrm{C}$ ) labeled tubes containing $200 \mathrm{mM} \mathrm{K}$-EDTA solution ( $20 \mu \mathrm{L}$ per $\mathrm{mL}$ of blood). Following sampling equal volume of heparinized saline was flushed into the catheter. The blood samples were centrifuged at $5000 \mathrm{~g}$ for $5 \mathrm{~min}$ at $4 \pm 2{ }^{\circ} \mathrm{C}$ within $30 \mathrm{~min}$ of scheduled time. The plasma samples were placed in labeled tubes and immediately stored below -60 until their bioanalysis.

These studies were performed at Advinus Therapeutics Limited under approved study numbers N1819-N1822. 


\subsubsection{Repeat Dose Safety Study in Mice}

To determine the toxicity of UV-12 following 10 day repeat dose oral (by gavage) administration to male Swiss Albino mice, a high dose level of $100 \mathrm{mg} / \mathrm{kg}$ body weight was selected. The vehicle control and treatment group consisted of 5 male mice each aged 8-9 weeks at the start of the study. The dose formulation was administered to each group three times a day with approximately $8 \mathrm{~h}$ between each administration for 10 consecutive days. The dosing volume administered to each mouse per administration was $0.3 \mathrm{~mL} /$ dose. All mice were observed for mortality and morbidity twice daily during treatment period. Parameters evaluated were mortality, clinical signs, body weights, food consumption, fasting body weight, clinical chemistry, organ weights, gross pathology and histopathology. The food consumption was measured during Days 1-4, 4-7 and 7-10 for all groups. The amount of spillage was considered for calculation of food consumption. All mice at the end of the treatment period (on Day 11) were fasted for 3 to $5 \mathrm{~h}$ (water allowed) and retro-orbital sinus was punctured to collect blood using a fine capillary tube under isoflurane anaesthesia. Blood samples were collected in tubes containing lithium heparinized tubes for determination of clinical chemistry parameters. Plasma was separated by centrifuging the whole blood samples at $4{ }^{\circ} \mathrm{C}, 5000 \mathrm{rpm}$ for $10 \mathrm{~min}$ and analyzed using Roche/Hitachi 902 Analyzer (Hitachi High-Technologies Corporation, Tokyo, Japan) for the following parameters: Alanine Aminotransferase, Albumin, Alkaline phosphatase, Aspartate Aminotransferase, Blood Urea Nitrogen, Creatinine, Gamma Glutamyl Transpeptidase, Glucose, Inorganic phosphorous, Potassium, Sodium, and Total Cholesterol. All mice at the end of the treatment period were subjected to detailed necropsy and findings were recorded. All mice were fasted for 3 to $5 \mathrm{~h}$ (water allowed), weighed, anaesthetized with isoflurane, exsanguinated and subjected for gross examination. On completion of the gross pathology examination, a total of 43 tissues and organs were collected from each mouse. Selected organs and tissues were weighed. The organ weight ratios as percentage of body and brain weight was determined. 10\% Neutral Buffered Formalin (NBF) was used for fixation. The tissues were processed for routine paraffin embedding and 4-5 micron sections were stained with Mayer's Haematoxylin and Eosin stain. Histopathological examination was carried out on the preserved organs of all mice. Data for this study was captured using Provantis ${ }^{\mathrm{TM}}$ : Parameters such as body weight, net body weight gains (derived data), food consumption (derived data), terminal fasting body weight, laboratory investigations-clinical chemistry, organ weights and their ratios data (derived data) was analyzed using Provantis ${ }^{\mathrm{TM}}$ built-in statistical tests. All analyses and comparisons were evaluated at the $5 \%(p \leq 0.05)$ level. This study was performed at Advinus Therapeutics Limited under approved study number N1896).

\section{Results}

\subsection{In Vitro $\alpha$-Glucosidase Activity of $U V-12$}

UV-12 inhibits both $\alpha$-glucosidase I and II in a purified enzyme assay with $\mathrm{IC}_{50}$ ranging from $0.14 \mu \mathrm{M}$ for $\alpha$-glucosidase I to $0.83-1.1 \mu \mathrm{M}$ for $\alpha$-glucosidase II (Table 1 ). The assay uses purified $\alpha$-glucosidases I and II from rat liver and shows UV-12 to have a greater inhibition against $\alpha$-glucosidase I compared to $\alpha$-glucosidase II. There was no significant difference in the inhibitory potential of UV-12 against the two activities of $\alpha$-glucosidase II in vitro. 
UV-12 also inhibited ER $\alpha$-glucosidase enzymes in a cell-based assay (Figure 2a). The FOS assay uses glycan biomarkers of ERAD to monitor $\alpha$-glucosidase I and II inhibition. The assay shows UV-12 causes an initial increase in the levels of mono-glucosylated free glycans at low concentrations, and therefore $\alpha$-glucosidase II inhibition. Subsequently, there is an increase in tri-glucosylated FOS as UV-12 concentrations are increased, allowing demonstration of ER $\alpha$-glucosidase I inhibition. Since $\alpha$-glucosidase I functions at an earlier step in the N-linked glycoprotein biosynthetic pathway, a decrease in the level of mono-glucosylated free glycans produced in the cell is not observed until higher UV-12 concentrations.

The cellular half-life of UV-12 inhibition as shown by blockage of $\alpha$-glucosidase I is $5.11 \pm 1.82 \mathrm{~h}$ in MDBK cells (Figure 2b) when monitoring the biomarker of this inhibition in the ER [23]. Glc3Man7GlcNAc2 is produced in the ER upon $\alpha$-glucosidase I inhibition by UV-12 at $50 \mu \mathrm{M}$ and the level of this FOS species can be followed upon removal of UV-12. This demonstrates that the $\alpha$-glucosidase blockage has been removed with the removal of the terminal glucose from the Glc3Man7GlcNAc2 FOS species in the ER occurring by the activity of $\alpha$-glucosidase I and demonstrates that UV-12 is a reversible inhibitor in cells.

Table 1. Iminosugars are potent ER $\alpha$-glucosidase inhibitors and can inhibit viral replication in vitro. UV-12 was tested for the ability to inhibit rat liver ER $\alpha$-glucosidases I and II on oligosaccharide substrates, $\operatorname{Glc}_{(1-3)} \operatorname{Man}_{(4-7)} \operatorname{GlcNAc}_{(1-2)}$ isolated from cultured cells. The mean and $\mathrm{SD}$ of the $\mathrm{IC}_{50}$ from triplicate assays is shown. Viral inhibition was tested using a yield/plaque assay with multiple concentrations of UV-12. The mean from duplicate assays is shown.

\begin{tabular}{ccccccc}
\hline \multirow{2}{*}{ Compound } & a-glc I & \multicolumn{2}{c}{$\boldsymbol{\alpha}$-glc II } & \multicolumn{3}{c}{ Virus } \\
\cline { 2 - 6 } & Glc $_{3}$ & \multicolumn{2}{c}{ Glc $_{2}$ Glc $_{1}$} & DENV-2 & INFV & VEEV \\
\hline UV-12 & $0.14 \pm 0.10 \mu \mathrm{M}$ & $1.10 \pm 0.48 \mu \mathrm{M}$ & $0.83 \pm 0.37 \mu \mathrm{M}$ & $21.71 \mu \mathrm{M}$ & $>250 \mu \mathrm{M}$ & $69.4 \mu \mathrm{M}$ \\
\hline
\end{tabular}

a

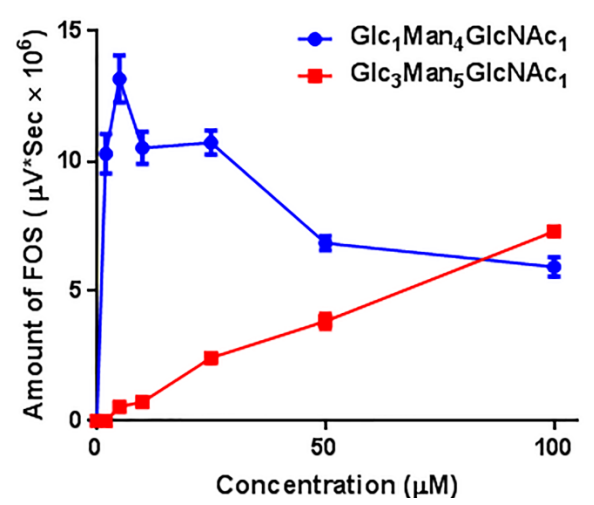

b

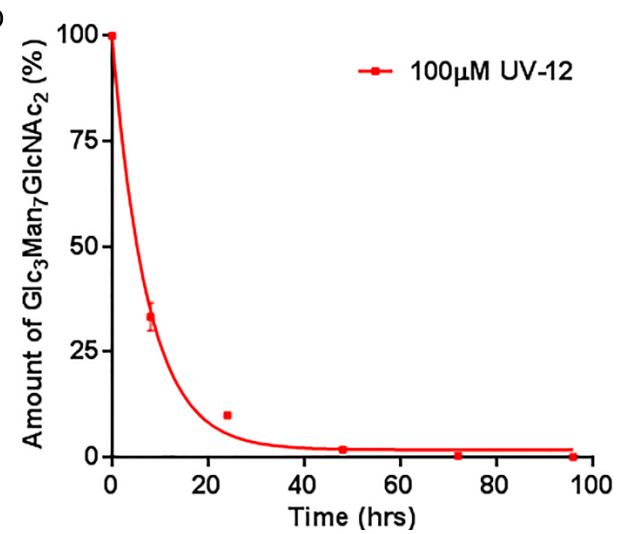

Figure 2. Rates of glucosylated FOS generated in the presence of the $\alpha$-glucosidase inhibitor UV-12. (a) Levels of a monoglucosylated and triglucosylated FOS species generated over a concentration range of UV-12 are shown. The products of glucosidase II inhibition (Glc $1 \mathrm{Man}_{4} \mathrm{GlcNAc}_{1}$ as the exemplar) and glucosidase I inhibition (Glc $3 \mathrm{Man}_{5} \mathrm{GlcNAc}_{1}$ as the exemplar) are indicated; (b) Cellular half-life of UV-12 determined based on ER $\alpha$-glucosidase I inhibition (generation of Glc $3 \mathrm{Man}_{7} \mathrm{GlcNAc}_{2}$ as the readout) are indicated. Fluorescently labeled FOS species were isolated from cells at various times following treatment with $100 \mu \mathrm{M} \mathrm{UV}-12$. The mean and SD from triplicate assays is shown in each graph. 


\subsection{Antiviral Activity of $U V-12$}

\subsubsection{In Vitro Activity of UV-12}

The $\mathrm{CC}_{50}$ of UV-12 in Vero and MDCK cells was $>500 \mu \mathrm{M}$. To assess the number and infectivity of daughter virions produced in the presence of UV-12, a yield assay followed by plaque assay (DENV and VEEV) or TCID (INFV) was used. UV-12 inhibited DENV-2 and VEEV but not INFV in vitro (Table 1). The IC50 for UV-12 was $21.71 \mu \mathrm{M}$ for DENV-2, $69.4 \mu \mathrm{M}$ for VEEV, and $>250 \mu \mathrm{M}$ for INFV (H1N1).

\subsubsection{Antiviral Activity of UV-12 against Influenza}

We have recently demonstrated efficacy of the UV-4 iminosugar against influenza [18]. In order to determine whether UV-12 could also promote survival of mice infected with INFV, UV-12 was delivered $\sim 60$ min prior to viral challenge with lethal mouse-adapted INFV A/Texas/36/91 (H1N1) via oral gavage at $100,80,60,40$, or $20 \mathrm{mg} / \mathrm{kg}$ and continued three times daily for 10 days. While UV-12 did not inhibit in vitro INFV replication, treatment with UV-12 dosed thrice daily for 10 days protected mice challenged with INFV (Figure 3a). Mice that were treated with $100 \mathrm{mg} / \mathrm{kg}$ of UV-12 displayed $100 \%$ survival and the groups that were treated with 80 and $60 \mathrm{mg} / \mathrm{kg}$ each displayed $90 \%$ survival. The group treated with $40 \mathrm{mg} / \mathrm{kg}$ of UV-12 displayed 50\% survival and a mean survival time of 9 days, while the vehicle-control group and group treated with $20 \mathrm{mg} / \mathrm{kg}$ displayed $0 \%$ survival and a mean survival of 9 and 7 days, respectively. Therefore, the minimum effective dose for UV-12 is $60 \mathrm{mg} / \mathrm{kg}$ (Figure 3a).

To determine the therapeutic window of UV-12 in the influenza mouse model, UV-12 was administered starting at $-1,+24,+48,+72 \mathrm{~h}$ relative to challenge at 100 (Figure $3 \mathrm{~b}$ ) or $60 \mathrm{mg} / \mathrm{kg}$ (Figure $3 \mathrm{c}$ ). At the dose of $100 \mathrm{mg} / \mathrm{kg}$, mice that were treated starting at $-1 \mathrm{~h}$ displayed $100 \%$ survival and the group that was treated at $+24 \mathrm{~h}$ displayed $70 \%$ survival. Mice that were treated starting at +48 or $+72 \mathrm{~h}$ post-infection displayed $0 \%$ survival. In these groups, $100 \%$ mortality was delayed by one day compared to the vehicle (water) control. When UV-12 was administered at $60 \mathrm{mg} / \mathrm{kg}$, the groups that were treated at $-1,+24 \mathrm{~h},+48$, and $+72 \mathrm{~h}$ displayed $80,60,80$, and $40 \%$ survival, respectively, compared to mice treated with vehicle in the study displaying $0 \%$ survival. Therefore, UV-12 dosed at 100 or $60 \mathrm{mg} / \mathrm{kg}$ can provide protection when dosing starts after infection.

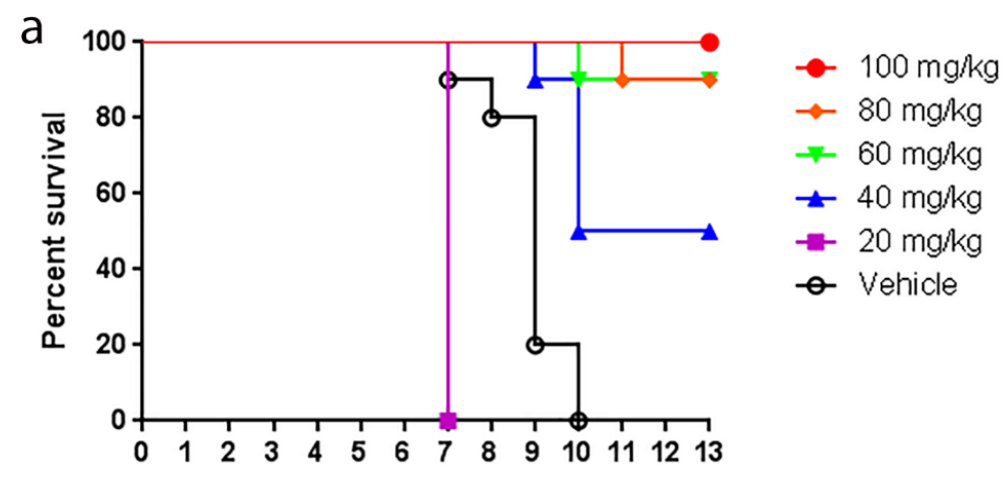

Figure 3. Cont. 

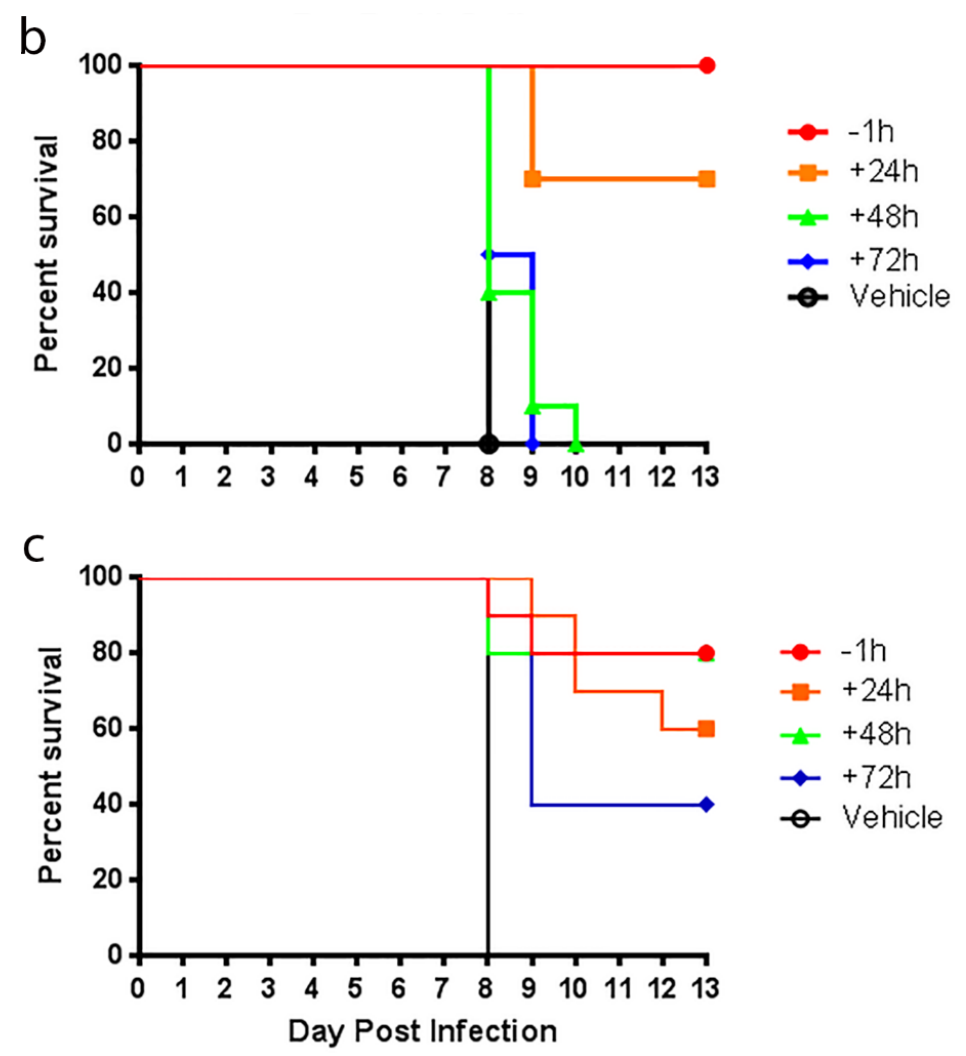

Figure 3. Protection by UV-12 in an INFV H1N1 mouse model. (a) BALB/c mice ( $n=10$ /group) were treated orally with $100,80,60,40$ or $20 \mathrm{mg} / \mathrm{kg}$ of UV-12 or vehicle only thrice daily for 10 days starting $1 \mathrm{~h}$ before infection with $\sim 1 \mathrm{LD}_{90}$ of mouse-adapted INFV A/Texas/36/91 ( $\sim 52$ plaque forming units); (b)-(c) BALB/c mice ( $n=10 /$ group) received the first treatment dose of $100 \mathrm{mg} / \mathrm{kg}$ (b) or $60 \mathrm{mg} / \mathrm{kg}$ (c) of UV-12 starting at -1 , 24,48 , or $72 \mathrm{~h}$ relative to infection with $\sim 1$ LD 90 of INFV A/Texas/36/91 via IN instillation. Treatment began at the time point indicated and continued TID every $8 \mathrm{~h}$ for a total of 10 days.

\subsubsection{Antiviral Activity of UV-12 against Dengue}

In vivo efficacy of UV-12 was also tested using a DENV antibody-dependent enhancement (ADE) in AG129 mice lacking both type I and type II interferon receptors. In this model, the virus $\left(1 \times 10^{4} \mathrm{pfu}\right)$ is administered in combination with $15 \mu \mathrm{g}$ of monoclonal antibody $2 \mathrm{H} 2$ (ATCC, Manassas, VA, USA) one hour before the viral challenge [16,27]. Using this ADE AG129 mouse model, UV-12 protected $100 \%$ of animals when administered at 100 or $20 \mathrm{mg} / \mathrm{kg}$ starting at $1 \mathrm{~h}$ before viral challenge (Figure 4). Mice treated with vehicle only had $0 \%$ survival and a mean time to death of 5 days.

To examine the effect of UV-12 on virus replication on DENV in vivo, infected mice were treated with $100 \mathrm{mg} / \mathrm{kg}$ starting at $1 \mathrm{~h}$ before infection until the time of harvest. All the mice in this study were predetermined for sampling at 72 or $96 \mathrm{~h}$ post infection and euthanized for this purpose at each time point. Blood, liver, kidneys, spleen and small intestines were harvested at the indicated time points and titrated using qRT-PCR. Viral loads were reduced in the kidneys (statistical significance at 72 and $96 \mathrm{~h}$ time points with a 12.9- and 5.23-fold decrease) and small intestine (statistical significance at $72 \mathrm{~h}$ post infection with a 6.1-fold decrease) in UV-12 treated DENV infected animals as compared those treated 
with vehicle only (Figure 5) but not reduced in the serum, liver or spleens at the time points sampled in this study. A 5-fold increase in virus titers was observed at the $72 \mathrm{~h}$ time point in spleens of the UV-12 treated mice but the groups did not have a difference at the later time point tested.

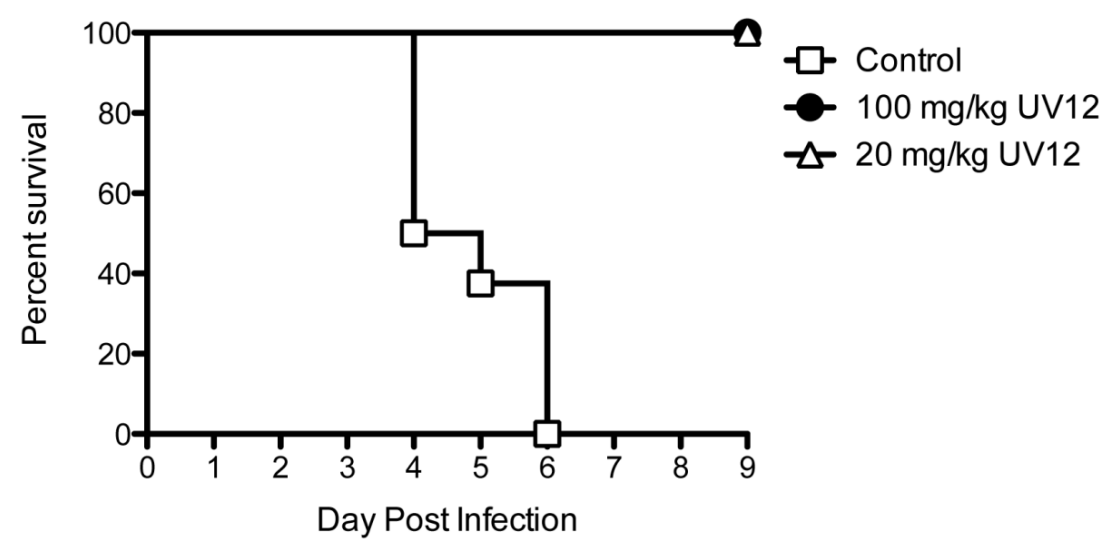

Figure 4. Protection by UV-12 in DENV ADE mouse model. AG129 mice were treated with 100 or $20 \mathrm{mg} / \mathrm{kg}$ of UV-12 orally thrice daily for 7 days starting $1 \mathrm{~h}$ before challenge using the ADE DENV model.
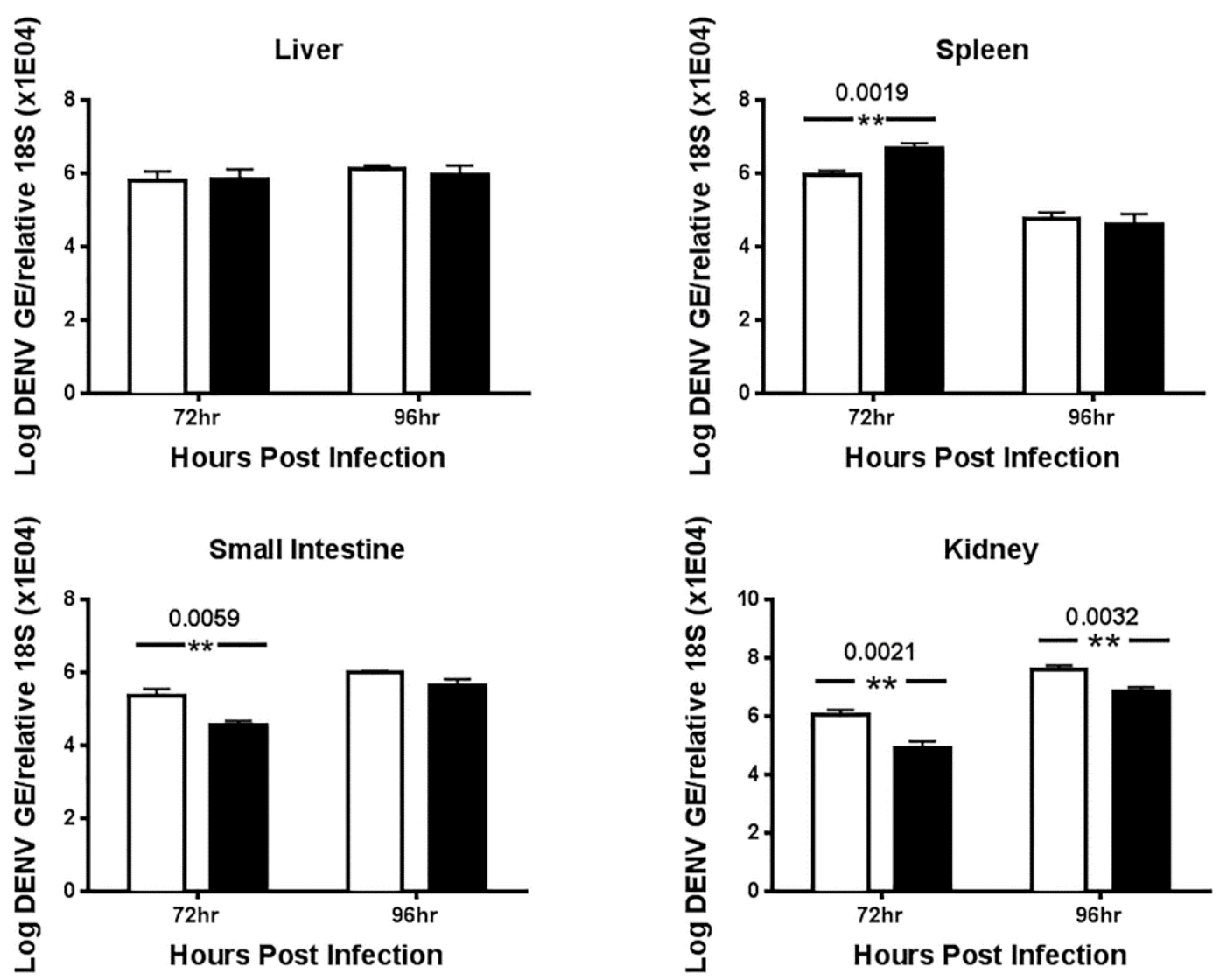

Figure 5. Cont. 


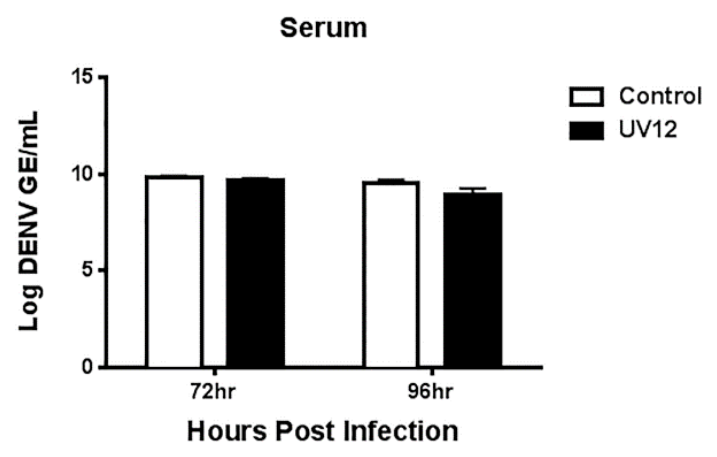

Figure 5. Dengue viral titer determined using qRT-PCR in serum or tissues collected from UV-12 treated AG129 mice. Groups of AG129 mice received the first treatment dose of $100 \mathrm{mg} / \mathrm{kg}$ of UV-12 or vehicle control $1 \mathrm{~h}$ before infection with DENV2 at a dose of $\sim 1 \mathrm{LD}_{90}$. Treatment continued three times daily at $8 \mathrm{~h}$ intervals until tissue harvest at 72 or $92 \mathrm{~h}$ post infection. Viral titers in the serum or liver, spleen, kidney and small intestines were determined by qRT-PCR for each sample from individual animals and the mean with standard deviation are also shown for each group. Data are shown as log DENV genome equivalents per $\mathrm{mL}$ of serum or as $\log \mathrm{DENV}$ genome equivalents per relative $18 \mathrm{~S}\left(\times 10^{4}\right)$ for the tissues analyzed. Statistical differences $(p<0.05)$ are indicated with the actual values over the relevant data points.

Lethal dengue infections, especially in the case of dengue shock syndrome and dengue hemorrhagic fever, are associated with high levels of circulating cytokines and chemokines. Therefore, the effect of UV-12 treatment on cytokine responses was also examined in serum of DENV mice from the samples taken in the study described above. Treatment with UV-12 dampened the overall circulating cytokine levels in the DENV infected AG129 mice as compared to the vehicle only treated mice (Figure 6). Specifically, TNF- $\alpha$, GM-CSF, MIP-1 $\alpha$, IL-1 $\alpha$, IL-1 $\beta$, IL-2, IL-3, IL-12p40, IL-12p70, and IL-17 levels were significantly reduced in UV-12 animals compared to vehicle control treated mice at both the 72 and $96 \mathrm{~h}$ post infection time points. Levels of IFN- $\gamma$ were significantly reduced only at the $72 \mathrm{~h}$ time point and MIP-1 $\beta$, RANTES, and IL-10 levels were reduced only at the $96 \mathrm{~h}$ post infection time point. There was an apparent reduction in MCP-1 in the UV-12 treated mice at the $72 \mathrm{~h}$ time point but the difference was not significant $(p=0.0641)$ KC was the only chemokine that had significantly higher levels (at the $72 \mathrm{~h}$ time point only) in UV-12 treated mice as compared to the control animals. Levels of IL-9 and eotaxin were not different (not shown). 

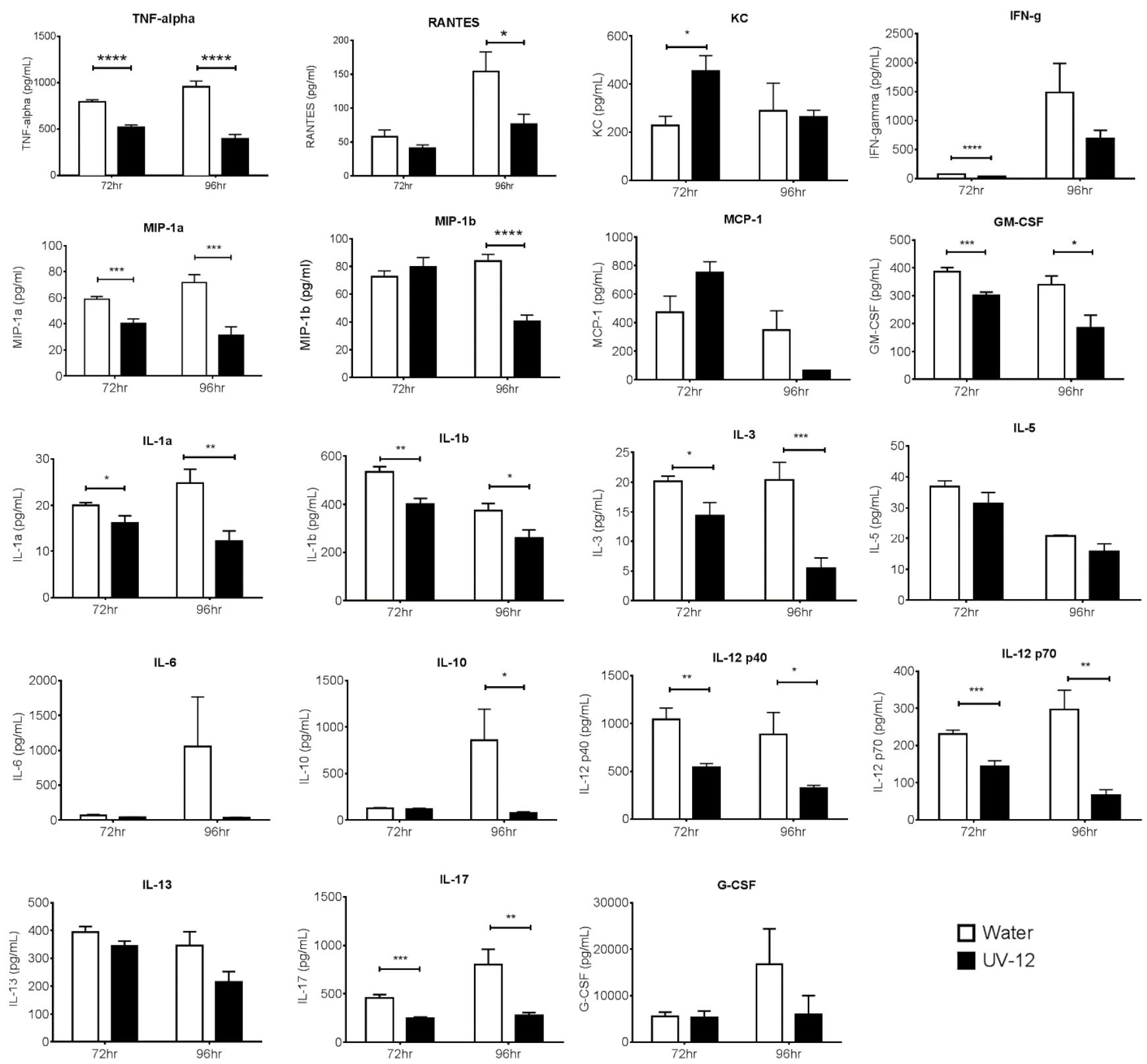

Figure 6. Cytokine levels in serum collected from UV-12 treated AG129 mice. Groups of AG129 mice received the first treatment dose of $100 \mathrm{mg} / \mathrm{kg}$ of UV-12 or vehicle control $1 \mathrm{~h}$ before infection with DENV2 at a dose of $\sim 1 \mathrm{LD} 90$. Treatment continued three times daily at $8 \mathrm{~h}$ intervals until harvest at 72 or $92 \mathrm{~h}$ post infection followed by analysis for levels of G-CSF, GM-CSF, IFN- $\gamma$, IL-1 $\alpha$, IL-1 $\beta$, IL-2, IL-3, IL-4, IL-5, IL-6, IL-10, IL-12 (p40), IL-12 (p70), IL-13, IL-17A, KC, MCP-1 (MCAF), MIP-1 $\alpha$, MIP-1 $\beta$, RANTES and TNF- $\alpha$ via multiplex assay. Statistical significance is indicated above sets of data where the $p$ value $<0.05(*),<0.01(* *),<0.001(* * *)$, and $<0.0001(* * * *)$.

\subsection{Absorption-Distribution-Metabolism-Elimination (ADME), Pharmacokinetic (PK) and Safety Studies}

\subsubsection{ADME Studies}

UV-12 was tested in a standard panel for drug-like properties (i.e., potential for bioavailability, solubility, and metabolic stability) and characterized for safety that predict whether a molecule is likely 
to be a clinical drug candidate. The findings of the in vitro ADMET studies that were conducted for UV-12 are summarized in Table 2.

Table 2. In vitro ADME properties of UV-12.

\begin{tabular}{|c|c|c|c|}
\hline Caco-2 permeability & Efflux Ratio & \multicolumn{2}{|c|}{4} \\
\hline \multirow{4}{*}{$\begin{array}{l}\text { Plasma protein binding } \\
\text { (\% bound at } 10 \mathrm{uM})\end{array}$} & Human & \multicolumn{2}{|c|}{$68 \%$} \\
\hline & Dog & \multicolumn{2}{|c|}{$72 \%$} \\
\hline & Rat & \multicolumn{2}{|c|}{$68 \%$} \\
\hline & Mouse & \multicolumn{2}{|c|}{$64 \%$} \\
\hline \multirow{5}{*}{$\begin{array}{c}\text { Liver microsome metabolic } \\
\text { stability }(0.5 \mathrm{mg} / \mathrm{mL} \\
\text { protein concentration })\end{array}$} & & $\mathrm{CL}_{\text {intr }}(\mathrm{mL} / \mathrm{min} /$ & Half-life (min) \\
\hline & Human & $<0.6$ & $>30$ \\
\hline & Dog & $<0.6$ & $>30$ \\
\hline & Rat & $<0.6$ & $>30$ \\
\hline & Mouse & $<0.6$ & $>30$ \\
\hline \multirow{5}{*}{ CYP inhibition $\left(\mathrm{IC}_{50}\right)$} & CYP1A2 & \multicolumn{2}{|c|}{$>100 \mu \mathrm{M}$} \\
\hline & CYP2C9 & \multicolumn{2}{|c|}{$>100 \mu \mathrm{M}$} \\
\hline & CYP2C19 & \multicolumn{2}{|c|}{$>100 \mu \mathrm{M}$} \\
\hline & CYP2D6 & \multicolumn{2}{|c|}{$>100 \mu \mathrm{M}$} \\
\hline & CYP3A4 $4^{\mathrm{a}}$ & \multicolumn{2}{|c|}{$>100 \mu \mathrm{M}$} \\
\hline \multicolumn{2}{|c|}{ hERG Inhibition } & \multicolumn{2}{|c|}{$>300 \mu \mathrm{M}$} \\
\hline \multicolumn{2}{|c|}{ Mini-Ames } & \multicolumn{2}{|c|}{ Not mutagenic up to $5 \mathrm{mg} /$ plate } \\
\hline
\end{tabular}

As a preliminary assessment of the predicted bioavailability of UV-12, transport across Caco-2 cells was tested as an in vitro model of human small intestinal tissues. There is a well-established correlation between the in vitro apparent permeability (Papp) across Caco-2 cells and gastric absorption [30]. The efflux ratio $(\mathrm{EF})$ in a $\mathrm{Caco} 2$ permeability assay was moderate $(\mathrm{EF}=4$, Table 2$)$, predicting moderate transport across the gastrointestinal lumen into the blood stream but also indicating it may be a transporter substrate (ex. PGP or BCRP).

Another predictor of drug likeness is the degree to which the compound binds to plasma proteins. The more binding to proteins, the less drug that is available in the unbound form to exhibit the desired effect. Plasma protein binding was moderate and comparable across four species ranging from $64 \%$ in the mouse to $72 \%$ in the dog (Table 2 ).

More than half of marketed small molecules are cleared by hepatic CYP-mediated metabolism [31]. Liver microsomes are subcellular fractions that contain membrane bound drug metabolizing enzymes including CYP and can be used to predict the metabolism and clearance of a compound in vivo. UV-12 was not metabolized by mouse, rat, dog or human liver microsomes (100\% parent drug remained after $30 \mathrm{~min}$ ) predicting good in vivo stability and low liability for rapid clearance. The metabolism of drugs can be divided into three stages including modification, conjugation, and excretion. One of the most common metabolic pathways is hydroxylation by cytochrome (CYP) enzymes. Inhibition of the CYP enzymes can increase the duration and intensity of drug exposure. To determine whether UV-12 inhibited any of the most common CYP enzymes, a standard assay format was used. UV-12 did not inhibit the five cytochrome P450s tested (CYP1A2, CYP2C9, CYP2C19, CYP2D6, and CYP3A4 (both midazolam and testosterone substrates)) at concentrations up to $100 \mu \mathrm{M}$ (Table 2). 
The inhibition of the hERG channel is used as a surrogate to predict the potential of cardiovascular risk of a drug candidate. Using a standard patch-clamp assay, concentrations of $0,30,100$ and $300 \mu \mathrm{M}$ of UV-12 showed inhibition of hERG current at $6.3 \%, 18.2 \%, 4.6 \%$ and $19.1 \%$ respectively, while the positive control compound propafenone hydrochloride showed $82.9 \%$ inhibition. These results suggested that UV-12 is not an inhibitor of the hERG potassium channel (Table 2).

The Ames test is an assay for potential mutagenicity of test articles. Reversion of the strains to enable growth on minimal media is indicative of mutation-inducing nature of the test article. UV-12 was not mutagenic in a mini-Ames assay up to the top dose of $5000 \mu \mathrm{g} /$ plate (Table 2).

\subsubsection{Safety Data for UV-12 in Rodents}

To evaluate the toxicity potential and the maximum tolerated dose when administered to guinea pigs, UV-12 was delivered in a single bolus by the intramuscular route at $20,40,60,80$ and $100 \mathrm{mg} / \mathrm{kg}$ or by IV route at 10,20,40,60 and $80 \mathrm{mg} / \mathrm{kg}$ body weight. There were no clinical signs of toxicity or mortality observed in any of the treated dose groups during the observation period of 7 days. There were no gross abnormalities detected at necropsy. Based on these findings, the maximum tolerated dose of UV-12 in guinea pigs by the intramuscular route is $>100 \mathrm{mg} / \mathrm{kg}$ by the intramuscular route and $>80 \mathrm{mg} / \mathrm{kg}$ by the IV route, since these were the highest levels tested.

The oral administration of UV-12 to male mice at a dose of $100 \mathrm{mg} / \mathrm{kg}$ three times daily for 10 consecutive days resulted in neither mortality nor any noteworthy effects on general health of the animals, body weights, net body weight gains and food consumption. There was a difference, although not statistically significant, in weight of the treated and control animals. At the end of treatment period, treated animals lost an average of $4.53 \%$ weight (1.72 g), while control animals gained 3.97\% (1.44 g) compared to their starting weight. Amongst the clinical chemistry parameters evaluated, statistically significant increased AST (76\%) and decreased ALP (45\%) and glucose (29\%) in UV-12 treated mice were considered as treatment related. No other parameters were found to be statistically different between the control and treated groups. Upon necropsy, no test-item related gross findings were observed except in the thymus where lymphoid depletion observed microscopically in the UV-12 treated mice was associated with decreased thymus weight.

\subsubsection{Pharmacokinetic Study of UV-12 in Rodents}

In mice, absorption of an oral pharmacologic UV-12 dose (100 mg/kg) was rapid and demonstrated good oral bioavailability (F) of $77 \%$ as shown in Table 3. Plasma clearance (CL) was calculated at $28.22 \mathrm{~mL} / \mathrm{min} / \mathrm{kg}$ following IV administration. Toxicokinetics studies revealed that UV-12 exhibited rapid absorption following dosing with the median time to reach maximum plasma concentration $\left(\mathrm{T}_{\max }\right.$, $0.5 \mathrm{~h}$ ) post dose with a corresponding maximum plasma concentration $\left(\mathrm{C}_{\max }\right)$ of $8.88-12.59 \mu \mathrm{g} / \mathrm{mL}$. Following IV administration of UV-12 solution to mice, the mean plasma clearance (CL) was low $(28.22 \mathrm{~mL} / \mathrm{min} / \mathrm{kg}, 31 \%$ of mouse liver blood flow $90 \mathrm{~mL} / \mathrm{min} / \mathrm{kg})$. The mean volume of distribution at steady state (Vss) following IV administration was found to be high $(1.98 \mathrm{~L} / \mathrm{kg}$, 3-fold higher than the total body water of $0.65 \mathrm{~L} / \mathrm{kg}$ ). Following IV administration UV-12 was eliminated with a mean elimination half-life $\left(\mathrm{T}_{1 / 2}\right)$ of $1.92 \mathrm{~h}$ and $\mathrm{AUCl}_{\text {last }}(5.90 \mu \mathrm{g} . \mathrm{h} / \mathrm{mL})$ and $\mathrm{AUC}_{\text {inf }}(5.91 \mu \mathrm{g} . \mathrm{h} / \mathrm{mL})$ were less than after oral administration 43.14 and $45.54 \mu \mathrm{g} . \mathrm{h} / \mathrm{mL}$, respectively. 
Table 3. Mean pharmacokinetic parameters of UV-12 in male Swiss Albino mice.

\begin{tabular}{|c|c|c|c|c|c|c|c|c|}
\hline Route/Dose(mg/kg) & $\mathbf{T}_{\max }(\mathbf{h})$ & $\begin{array}{c}C_{\max } \\
(\mu \mathrm{g} / \mathrm{mL}) \\
\end{array}$ & $\begin{array}{c}\mathrm{AUC}_{\text {last }}{ }^{\mathrm{a}} \\
(\mu \mathrm{g} . \mathrm{h} / \mathrm{mL})\end{array}$ & $\begin{array}{c}\mathrm{AUC}_{\text {inf }}{ }^{\mathrm{a}} \\
(\mu \mathrm{g} . \mathrm{h} / \mathrm{mL})\end{array}$ & $\begin{array}{c}\text { CL } \\
(\mathrm{mL} / \mathrm{min} / \mathrm{kg})\end{array}$ & $\begin{array}{c}V_{\mathrm{ss}} \\
(\mathrm{L} / \mathrm{kg})\end{array}$ & $\mathbf{T}_{1 / 2}(\mathrm{~h})$ & $\mathbf{F}^{\mathbf{b}}$ \\
\hline $\mathrm{IV} / 10$ & NA & $8.88^{\mathrm{c}}$ & 5.90 & 5.91 & 28.22 & 1.98 & 1.92 & - \\
\hline $\mathrm{PO} / 100$ & 0.5 & 12.59 & 43.14 & 45.54 & $\mathrm{NC}$ & $\mathrm{NC}$ & $\mathrm{NC}$ & 77 \\
\hline
\end{tabular}

${ }^{\mathrm{a}} \mathrm{AUClast}$ calculated using data through $8 \mathrm{~h}$ and $\mathrm{AUC}_{\text {inf }}$ calculated using data extrapolated to infinity. ${ }^{\mathrm{b}} \mathrm{AUC}_{\mathrm{inf}}$ and nominal doses were used for bioavailability calculations; ${ }^{\mathrm{c}}$ back extrapolated concentration at time zero; NA: Not applicable; Regression points (4, 8 and $16 \mathrm{~h}$ ) were selected for both routes to calculate elimination rate constant. NC: Data results were not suitable to calculate $\mathrm{Cl}, \mathrm{V}_{\mathrm{ss}}$, and $\mathrm{T}_{1 / 2}$ for the oral route.

Mean pharmacokinetic parameters of UV-12 following subcutaneous, intramuscular and IV bolus administration of UV-12 solution in guinea pigs are summarized in Table 4. Following subcutaneous administration of UV-12 solution at a dose of $100 \mathrm{mg} / \mathrm{kg}$ body weight to female guinea pigs, the $\mathrm{T}_{\max }$ was found to be $0.5 \mathrm{~h}$ and $\mathrm{C}_{\max }$ was $11,035 \mathrm{ng} / \mathrm{mL}$. UV-12 was cleared from plasma with apparent half-life $\left(\mathrm{T}_{1 / 2}\right)$ of $2.21 \mathrm{~h}$. The subcutaneous absolute bioavailability was calculated as $131 \%$. Following intramuscular administration of UV-12 at a dose of $100 \mathrm{mg} / \mathrm{kg}$ body weight, the $\mathrm{T}_{\max }$ was found to be $0.25 \mathrm{~h}$ and $\mathrm{C}_{\max }$ was $11,636 \mathrm{ng} / \mathrm{mL}$. UV-12 was cleared from plasma with a $\mathrm{T}_{1 / 2}$ of $1.99 \mathrm{~h}$. The intramuscular absolute bioavailability was found to be $109 \%$. Following IV bolus administration of UV-12 solution at a dose of $25 \mathrm{mg} / \mathrm{kg}$ body weight, the CL of UV-12 was found to be $95.89 \mathrm{~mL} / \mathrm{min} / \mathrm{kg}$ and the Vss was determined to be $5.14 \mathrm{~L} / \mathrm{kg}$, which is $>8$-fold higher than the normal body water of $0.6 \mathrm{~L} / \mathrm{kg}$. UV-12 was cleared from plasma with a $\mathrm{T}_{1 / 2}$ of $1.40 \mathrm{~h}$.

Table 4. Mean pharmacokinetic parameters of UV-12 in female Hartley guinea pigs.

\begin{tabular}{|c|c|c|c|c|c|c|c|c|c|}
\hline Route & $\begin{array}{c}\text { Dose } \\
(\mathrm{mg} / \mathrm{kg})\end{array}$ & $\begin{array}{c}\mathbf{T}_{\max }{ }^{a} \\
\text { (h) }\end{array}$ & $C_{\max }(n g / m L)$ & $\begin{array}{c}\mathrm{AUC}_{\text {last }} \\
\text { (ng.h/mL) }\end{array}$ & $\begin{array}{c}\mathrm{AUC}_{\text {inf }} \\
\text { (ng.h/mL) }\end{array}$ & $\begin{array}{c}\text { CL } \\
(\mathrm{mL} / \mathrm{min} / \mathrm{kg})\end{array}$ & $\mathrm{V}_{\mathrm{ss}}(\mathrm{L} / \mathrm{kg})$ & $T_{1 / 2}(h)$ & $F^{b}$ \\
\hline $\mathrm{SC}$ & 100 & 0.5 & $11,035 \pm 3165$ & $23,023 \pm 5043$ & $23,078 \pm 5060$ & $\mathrm{NC}$ & $\mathrm{NC}$ & $2.21 \pm 0.37$ & 131 \\
\hline IM & 100 & 0.25 & $11,636 \pm 2247$ & $19,122 \pm 2088$ & $19,168 \pm 2094$ & $\mathrm{NC}$ & $\mathrm{NC}$ & $1.99 \pm 0.91$ & 109 \\
\hline IV & 25 & NA & $8855^{c} \pm 470$ & $4368 \pm 583$ & $4398 \pm 599$ & $95.89 \pm 12.69$ & $5.14 \pm 0.64$ & $1.40 \pm 0.09$ & $\mathrm{NA}$ \\
\hline
\end{tabular}

\section{Discussion}

Iminosugars have long been pursued as antivirals and their activity has been previously described in vitro (reviewed in [1]) and in animal models of retroviruses [11], herpes simplex virus [10], flaviviruses such as dengue [9,13,14,16] and Japanese encephalitis virus [17] and Ebola virus [15] infections. While several iminosugars have been tested safely in the clinic, when these approved agents were assessed for antiviral activity in humans against viruses such as human immunodeficiency virus [32], hepatitis $\mathrm{C}$ virus [8] and dengue [33], only modest reductions in viral titers were observed. We are developing novel iminosugars with enhanced antiviral activity. We have now demonstrated that the 
novel iminosugar UV-12 has antiviral activity in vivo against both INFV and DENV and positive drug-like properties, similar to a related DNJ analog UV-4 [18].

The in vitro $\mathrm{IC}_{50}$ values against the rat enzymes using natural substrates showing increased inhibitory activity against ER $\alpha$-glucosidase I compared to ER $\alpha$-glucosidase II. This opposite situation is seen in the cellular inhibition assay that analyzes the FOS produced by ERAD as biomarkers of $\alpha$-glucosidase I and II inhibition. In spite of this increased inhibition of $\alpha$-glucosidase I, in common with many other iminosugars, we have tested the FOS assay shows an initial buildup of monoglucosylated FOS species ( $\alpha$-glucosidase II inhibition) prior to increase in triglucosylated FOS species ( $\alpha$-glucosidase I inhibition) at higher UV-12 concentrations. This apparent discrepancy between isolated enzyme inhibition and FOS analysis can be explained by the kinetics of the reactions. Removal of the first glucose residue by $\alpha$-glucosidase I and the second glucose residue by $\alpha$-glucosidase II in cultured cells probably occurs at close to their limiting rates $\left(\mathrm{V}_{\max }\right)$, where addition of a competitive inhibitor, such as UV-12, has a limited effect on the observed rate. Removal of the third glucose residue by $\alpha$-glucosidase II is much slower, suggesting that the rate is not close to $V_{\max }$, and under these conditions a UV-12 has a much greater effect on the rate. Since $\alpha$-glucosidase II and calnexin both compete for the same substrate in the ER (Glc ${ }_{1} \mathrm{Man}_{9} \mathrm{GlcNAc}_{2}$-protein), if $\alpha$-glucosidase II is unable to hydrolyze the substrate bound to calnexin, the presence of calnexin will significantly reduce the free substrate concentration, hence reducing the rate. Alternatively, if $\alpha$-glucosidase II is able to hydrolyze the substrate bound to calnexin, the presence of calnexin is likely to change the $\mathrm{K}_{\mathrm{m}}$. An increase in $\mathrm{K}_{\mathrm{m}}$ would also result in a reduced rate. Both possibilities have the same functional outcome: The rate of removal of the proximal glucose residue is reduced in cells and hence is more sensitive to the presence of a competitive inhibitor, resulting in a greater accumulation of mono-glucosylated glycans as seen in the FOS analysis.

The in vivo antiviral activity of ER $\alpha$-glucosidase inhibitors against INFV had not been demonstrated until our recent report of efficacy of UV-4 against INFV A (H1N1) [18]. Although we were not able to demonstrate inhibition of INFV replication in vitro using the yield-TCID assay in MDCK cells, UV-12 efficiently promoted survival in a lethal INFV mouse model. We are currently pursuing ex vivo screening models using primary cells and tissues to determine if their use may have a better correlation with in vivo efficacy as compared to our use of immortalized cell lines in our work to date. There are a large number of publications that have demonstrated the ability of iminosugars to modulate the glycosylation pattern of the influenza glycoproteins neuraminidase and haemagglutinin [34-37] and their interactions with calnexin and calreticulin and, in certain cases, reduce virus replication in vitro [12]. However, this appears to be a virus strain- and cell type- specific phenomenon that is not fully explained at this time [36,38-42]. Future directions of our work with UV-12 will be to explore activity against a wider panel of INFV (ex. H3N2, H5N1 and H7N9) in addition to a more diverse panel of viruses.

UV-12 inhibited DENV both in vitro and in a lethal DENV-2 mouse model. UV-12 promoted survival in the stringent ADE DENV-2 mouse model at both 20 and $100 \mathrm{mg} / \mathrm{kg}$ when dosed three times daily when administered starting as late as $48 \mathrm{~h}$ after infection. Following treatment with UV-12, reductions in viral loads were only noted in the kidneys and small intestine but not the serum, liver or spleens at the time points sampled in this study. These results are slightly different than the findings for UV-4; however, UV-12 was able to promote survival in the same dose range as UV-4 (10-20 mg/kg) in the DENV-2 ADE mouse model [16]. The relevance of the apparent difference in the ability to reduce the virus load in various tissues when comparing the efficacy of these two molecules is unclear at this time. 
Treatment of the DENV-2 infected mice with UV-12 resulted in lower levels of circulating cytokines and chemokines including pro-inflammatory molecules such as TNF- $\alpha$, GM-CSF, MIP-1 $\alpha$, IL-1 $\alpha$, IL-1 $\beta$, IL-2, IL-3, IL-12p40, IL-12p70, and IL-17 at 72 and $96 \mathrm{~h}$ after infection, IFN- $\gamma$ at the $72 \mathrm{~h}$ time point and MIP-1 $\beta$, RANTES, and IL-10 only at the $96 \mathrm{~h}$ time point. The reductions in mortality, disease signs/symptoms, and cytokine levels, are similar to our previous report on related iminosugar, UV-4 [16] that is currently being evaluated in a Phase 1 clinical trial. The reason for the overall decreased cytokine response observed in UV-12 treated mice, as compared to the vehicle control mice, is not clear. It could either be a result of decreased viral loads, symptomology and subsequent immune responses, changes in the morphology or structure of dengue virus produced in the presence of UV-12 that stimulate inflammatory responses [43] or be linked to direct effects on cytokine production mediated directly by UV-12. The mechanism for cytokine modulation by UV-12 in DENV infections will need to be further explored.

In general, the iminosugar class has demonstrated good drug-like ADMET (absorption, distribution metabolism, elimination, toxicology) characteristics. Molecular weights, $\log \mathrm{P}$, and total polar surface area are generally low, which imply good solubility. Indeed, UV-12 was soluble at more than $100 \mathrm{mg} / \mathrm{mL}$ in acidified water, which was the highest concentration tested. UV-12 was not metabolized by liver microsomes nor did it inhibit five of the most common CYP isoenzymes. UV-12 had moderate plasma protein binding properties, was readily detected in mouse and guinea pigs at high concentrations after oral administration, and was orally bioavailable as had been predicted by the Caco- 2 cell permeability test. The PK of UV-12 was similar in mice and guinea pigs. Specifically, the $\mathrm{T}_{\max }$ was $0.25-0.5 \mathrm{~h}$, the $\mathrm{C}_{\max }$ was $8.85-11.64 \mu \mathrm{g} / \mathrm{mL}$, and the $\mathrm{AUC}$ and $\mathrm{T}_{1 / 2}$ for mice and guinea pigs were similar following UV-12 dosing. UV-12 was well tolerated in a repeat dose study for 10 days at $100 \mathrm{mg} / \mathrm{kg}$. All these tests point to good drug-like properties for UV-12 but further work in additional species would be required should this molecule be selected for future development.

There are currently three iminosugar compounds in clinical use: Miglustat (Zavesca ${ }^{\circledR}$ ) for the treatment of Gaucher's disease and Niemann-Pick type C, and miglitol (Glyset ${ }^{\circledR}$ ) and acarbose $\left(\right.$ Precose $^{\circledR}$ ) for the treatment of type II diabetes mellitus. In addition, two iminosugars are currently in development for the treatment of DENV including celgosivir (a pro-drug of castanospermine) that has been tested in several clinical studies and a hydrochloride salt of UV-4 that is currently being tested in a Phase 1 clinical trial. Together, these compounds provide a large safety database for the evaluation of the iminosugar class of compounds. The recent publication by Sadat et al. described two siblings with CDG-IIb having multiple neurologic complications and severe hypogammaglobulinemia, which may be associated with the absence of ER $\alpha$-glucosidase I. However, it should be noted that these children have complete and permanent absence of ER $\alpha$-glucosidase I including during fetal development. Notably, the approved status of several other iminosugars for chronic use provides strong evidence that iminosugars related to DNJ present no significant toxicological concerns. Partial blockage of host ER $\alpha$-glucosidases is not grossly deleterious to the host, as evidenced by long-term usage of NB-DNJ for treatment of Gaucher's disease. The proposed use of optimized iminosugar candidate(s) as an antiviral for acute viral diseases is not likely to be more than 7 to 10 days dosage, thus limiting the duration of inhibition of the host enzymatic pathways and reducing risk for mechanism-related side effects. Encouragingly, when mice were treated with $100 \mathrm{mg} / \mathrm{kg} / \mathrm{dose}$ (300 mg/kg/day) of UV-12, the only remarkable finding was lymphoid depletion in the thymus being observed microscopically in the UV-12 treated mice and associated with decreased thymus weight. Thymic acellularity has been 
noted before when DNJ-based iminosugars have been administered to the mouse. NB-DNJ administration leads to thymus weight loss but the effects are rapidly reversed following drug removal and seem to have no functional, i.e., immunological, consequence [20,44].

Iminosugars are glucomimetics with positive drug like properties that have been well known for many years and several are approved for use in humans. The iminosugars are ER $\alpha$-glucosidase inhibitors that have antiviral activity with a reduced likelihood for generation of antiviral resistance due to targeting of host-based mechanisms. For these reasons, iminosugars offer an attractive avenue for developing broad spectrum antiviral therapies. Iminosugars with significant potency and good drug-like properties should be pursued as clinical candidates for treatment of diverse viral infections. UV-12 or more potent derivatives will be further studied and considered for advanced development.

\section{Acknowledgments}

The authors wish to thank Gretchun Kim, Catherine Wells, Gina Reed, Rafael Campos, Nicole Roberts, William Eddy, William Tang, Marisa Sanchez, and Yunichel Joo for technical assistance, as well as Raymond Dwek, Nicole Zitzmann, Brennan Klose, Anthony M. Treston, Christina Hedberg, Matthew Duchars and Michael Callahan for helpful discussions and critical review of the manuscript. Unither Virology, and its parent company, United Therapeutics, provided support in the form of salaries for authors (Kelly L. Warfield, Aruna Sampath and Urban Ramstedt), funding and resources to perform the studies described herein.

\section{Author Contributions}

K.L.W., A.S., G.W.W., E.P., S.S., D.S.A., S.G.E. and E.J.S. wrote or edited the manuscript. T.N. and U.R. designed the UV-12 molecule. K.L.W., T.D.B., E.P., D.S.A., S.G.E. and E.J.S. performed experiments described. K.L.W., A.S., U.R., T.D.B., G.W.W., E.P., S.S., D.S.A., S.G.E. and E.J.S. designed the studies or interpreted data.

\section{Conflicts of Interest}

K.L.W, A.S., and U.R. are current or former employees of Unither Virology. T.N., T.D.B. and G.W.W. performed portions of this work under consultancy agreements. E.P., S.S., D.S.A., S.G.E., and E.J.S. were all employees of institutions who received funding to perform portions of the work described.

\section{References}

1. Chang, J.; Block, T.M.; Guo, J.T. Antiviral therapies targeting host ER alpha-glucosidases: Current status and future directions. Antivir. Res. 2013, 99, 251-260.

2. Dalziel, M.; Crispin, M.; Scanlan, C.N.; Zitzmann, N.; Dwek, R.A. Emerging principles for the therapeutic exploitation of glycosylation. Science 2014, 343, 1235681.

3. Norton, P.A.; Gu, B.; Block, T.M. Iminosugars as antiviral agents. In Iminosugars: From Synthesis to Therapeutic Applications; Compain, P., Martin, O.R., Eds.; John Wiley \& Sons: Chichester, UK, 2007; pp. 207-224. 
4. Zitzmann, N.; Block, T.; Methta, A.; Rudd, P.; Burton, D.; Wilson, I.; Platt, F.; Butters, T.; Dwek, R.A. Glycosylation: Disease targets and therapy. Adv. Exp. Med. Biol. 2005, 564, 1-2.

5. Mehta, A.; Zitzmann, N.; Rudd, P.M.; Block, T.M.; Dwek, R.A. Alpha-glucosidase inhibitors as potential broad based anti-viral agents. FEBS Lett. 1998, 430, 17-22.

6. Sadat, M.A.; Moir, S.; Chun, T.W.; Lusso, P.; Kaplan, G.; Wolfe, L.; Memoli, M.J.; He, M.; Vega, H.; Kim, L.J.; et al. Glycosylation, hypogammaglobulinemia, and resistance to viral infections. N. Engl. J. Med. 2014, 370, 1615-1625.

7. Abian, O.; Alfonso, P.; Velazquez-Campoy, A.; Giraldo, P.; Pocovi, M.; Sancho, J. Therapeutic strategies for gaucher disease: Miglustat (nb-dnj) as a pharmacological chaperone for glucocerebrosidase and the different thermostability of velaglucerase alfa and imiglucerase. Mol. Pharm. 2011, 8, 2390-2397.

8. Durantel, D. Celgosivir, an alpha-glucosidase I inhibitor for the potential treatment of HCV infection. Curr. Opin. Investig. Drugs 2009, 10, 860-870.

9. Watanabe, S.; Rathore, A.P.; Sung, C.; Lu, F.; Khoo, Y.M.; Connolly, J.; Low, J.; Ooi, E.E.; Lee, H.S.; Vasudevan, S.G. Dose- and schedule-dependent protective efficacy of celgosivir in a lethal mouse model for dengue virus infection informs dosing regimen for a proof of concept clinical trial. Antivir. Res. 2012, 96, 32-35.

10. Bridges, C.G.; Ahmed, S.P.; Kang, M.S.; Nash, R.J.; Porter, E.A.; Tyms, A.S. The effect of oral treatment with 6-o-butanoyl castanospermine (mdl 28,574) in the murine zosteriform model of hsv-1 infection. Glycobiology 1995, 5, 249-253.

11. Ruprecht, R.M.; Mullaney, S.; Andersen, J.; Bronson, R. In vivo analysis of castanospermine, a candidate antiretroviral agent. J. Acquir. Immune Defic. Syndr. 1989, 2, 149-157.

12. Saito, T.; Yamaguchi, I. Effect of glycosylation and glucose trimming inhibitors on the influenza a virus glycoproteins. J. Vet. Med. Sci. 2000, 62, 575-581.

13. Chang, J.; Schul, W.; Butters, T.D.; Yip, A.; Liu, B.; Goh, A.; Lakshminarayana, S.B.; Alonzi, D.; Reinkensmeier, G.; Pan, X.; et al. Combination of alpha-glucosidase inhibitor and ribavirin for the treatment of dengue virus infection in vitro and in vivo. Antivir. Res. 2011, 89, 26-34.

14. Chang, J.; Schul, W.; Yip, A.; Xu, X.; Guo, J.T.; Block, T.M. Competitive inhibitor of cellular alpha-glucosidases protects mice from lethal dengue virus infection. Antivir. Res. 2011, 92, 369-371.

15. Chang, J.; Warren, T.K.; Zhao, X.; Gill, T.; Guo, F.; Wang, L.; Comunale, M.A.; Du, Y.; Alonzi, D.S.; Yu, W.; et al. Small molecule inhibitors of er alpha-glucosidases are active against multiple hemorrhagic fever viruses. Antivir. Res. 2013, 98, 432-440.

16. Perry, S.T.; Buck, M.D.; Plummer, E.M.; Penmasta, R.A.; Batra, H.; Stavale, E.J.; Warfield, K.L.; Dwek, R.A.; Butters, T.D.; Alonzi, D.S.; et al. An iminosugar with potent inhibition of dengue virus infection in vivo. Antivir. Res. 2013, 98, 35-43.

17. Wu, S.F.; Lee, C.J.; Liao, C.L.; Dwek, R.A.; Zitzmann, N.; Lin, Y.L. Antiviral effects of an iminosugar derivative on flavivirus infections. J. Virol. 2002, 76, 3596-3604.

18. Stavale, E.J.; Vu, H.; Sampath, A.; Ramstedt, U.; Warfield, K.L. In vivo therapeutic protection against influenza a (h1n1) oseltamivir-sensitive and resistant viruses by the iminosugar uv-4. PLOS ONE 2015, 10, e0121662.

19. Pollock, S.; Dwek, R.A.; Burton, D.R.; Zitzmann, N. N-Butyldeoxynojirimycin is a broadly effective anti-HIV therapy significantly enhanced by targeted liposome delivery. AIDS 2008, 22, 1961-1969. 
20. Alonzi, D.S.; Neville, D.C.; Lachmann, R.H.; Dwek, R.A.; Butters, T.D. Glucosylated free oligosaccharides are biomarkers of endoplasmic- reticulum alpha-glucosidase inhibition. Biochem. J. 2008, 409, 571-580.

21. Karlsson, G.B.; Butters, T.D.; Dwek, R.A.; Platt, F.M. Effects of the imino sugar n-butyldeoxynojirimycin on the n-glycosylation of recombinant gp120. J. Biol. Chem. 1993, 268, 570-576.

22. Olafson, R.W.; Thomas, J.R.; Ferguson, M.A.; Dwek, R.A.; Chaudhuri, M.; Chang, K.P.; Rademacher, T.W. Structures of the n-linked oligosaccharides of gp63, the major surface glycoprotein, from leishmania mexicana amazonensis. J. Biol. Chem. 1990, 265, 12240-12247.

23. Alonzi, D.S.; Kukushkin, N.V.; Allman, S.A.; Hakki, Z.; Williams, S.J.; Pierce, L.; Dwek, R.A.; Butters, T.D. Glycoprotein misfolding in the endoplasmic reticulum: Identification of released oligosaccharides reveals a second er-associated degradation pathway for golgi-retrieved proteins. Cell. Mol. Life Sci. 2013, 70, 2799-2814.

24. Food and Drug Administration. Guidance for Industry: S7a Safety Pharmacology Studies for Human Pharmaceuticals; Food and Drug Administration: Washington, DC, USA, 2001.

25. Food and Drug Administration. Guidance for Industry: S2(r1) Genotoxicity Testing and Data Interpretation for Pharmaceuticals Intended for Human Use; Food and Drug Administration: Washington, DC, USA, 2012.

26. Perry, S.T.; Prestwood, T.R.; Lada, S.M.; Benedict, C.A.; Shresta, S. Cardif-mediated signaling controls the initial innate response to dengue virus in vivo. J. Virol. 2009, 83, 8276-8281.

27. Zellweger, R.M.; Prestwood, T.R.; Shresta, S. Enhanced infection of liver sinusoidal endothelial cells in a mouse model of antibody-induced severe dengue disease. Cell Host Microbe 2010, 7, 128-139.

28. Prestwood, T.R.; Prigozhin, D.M.; Sharar, K.L.; Zellweger, R.M.; Shresta, S. A mouse-passaged dengue virus strain with reduced affinity for heparan sulfate causes severe disease in mice by establishing increased systemic viral loads. J. Virol. 2008, 82, 8411-8421.

29. Perry, S.T.; Buck, M.D.; Lada, S.M.; Schindler, C.; Shresta, S. Stat2 mediates innate immunity to dengue virus in the absence of stat1 via the type I interferon receptor. PLOS Pathog. 2011, 7, e1001297.

30. Artursson, P.; Karlsson, J. Correlation between oral drug absorption in humans and apparent drug permeability coefficients in human intestinal epithelial (caco-2) cells. Biochem. Biophys. Res. Commun. 1991, 175, 880-885.

31. Obach, R.S. Prediction of human clearance of twenty-nine drugs from hepatic microsomal intrinsic clearance data: An examination of in vitro half-life approach and nonspecific binding to microsomes. Drug Metab. Dispos. 1999, 27, 1350-1359.

32. Fischl, M.A.; Resnick, L.; Coombs, R.; Kremer, A.B.; Pottage, J.C., Jr.; Fass, R.J.; Fife, K.H.; Powderly, W.G.; Collier, A.C.; Aspinall, R.L.; et al. The safety and efficacy of combination n-butyl-deoxynojirimycin (sc-48334) and zidovudine in patients with HIV-1 infection and 200-500 cd4 cells/mm3. J. Acquir. Immune Defic. Synd. 1994, 7, 139-147.

33. Low, J.G.; Sung, C.; Wijaya, L.; Wei, Y.; Rathore, A.P.; Watanabe, S.; Tan, B.H.; Toh, L.; Chua, L.T.; Hou, Y.; et al. Efficacy and safety of celgosivir in patients with dengue fever (celaden): A phase $1 \mathrm{~b}$, randomised, double-blind, placebo-controlled, proof-of-concept trial. Lancet Infect. Dis. 2014, 14, 706-715. 
34. Hebert, D.N.; Foellmer, B.; Helenius, A. Calnexin and calreticulin promote folding, delay oligomerization and suppress degradation of influenza hemagglutinin in microsomes. EMBO J. 1996, 15, 2961-2968.

35. Hebert, D.N.; Foellmer, B.; Helenius, A. Glucose trimming and reglucosylation determine glycoprotein association with calnexin in the endoplasmic reticulum. Cell 1995, 81, 425-433.

36. Pan, Y.T.; Hori, H.; Saul, R.; Sanford, B.A.; Molyneux, R.J.; Elbein, A.D. Castanospermine inhibits the processing of the oligosaccharide portion of the influenza viral hemagglutinin. Biochemistry 1983, 22, 3975-3984.

37. Hammond, C.; Braakman, I.; Helenius, A. Role of n-linked oligosaccharide recognition, glucose trimming, and calnexin in glycoprotein folding and quality control. Proc. Natl. Acad. Sci. USA 1994, 91, 913-917.

38. Karaivanova, V.K.; Luan, P.; Spiro, R.G. Processing of viral envelope glycoprotein by the endomannosidase pathway: Evaluation of host cell specificity. Glycobiology 1998, 8, 725-730.

39. Hussain, S.; Miller, J.L.; Harvey, D.J.; Gu, Y.; Rosenthal, P.B.; Zitzmann, N.; McCauley, J.W. Strain-specific antiviral activity of iminosugars against human influenza a viruses. J. Antimicrob. Chemother. 2015, 70, 136-152.

40. Datema, R.; Romero, P.A.; Rott, R.; Schwarz, R.T. On the role of oligosaccharide trimming in the maturation of sindbis and influenza virus. Arch. Virol. 1984, 81, 25-39.

41. Romero, P.A.; Datema, R.; Schwarz, R.T. N-methyl-1-deoxynojirimycin, a novel inhibitor of glycoprotein processing, and its effect on fowl plague virus maturation. Virology 1983, 130, 238-242.

42. Kukushkin, N.V.; Easthope, I.S.; Alonzi, D.S.; Butters, T.D. Restricted processing of glycans by endomannosidase in mammalian cells. Glycobiology 2012, 22, 1282-1288.

43. Chen, S.T.; Lin, Y.L.; Huang, M.T.; Wu, M.F.; Cheng, S.C.; Lei, H.Y.; Lee, C.K.; Chiou, T.W.; Wong, C.H.; Hsieh, S.L. Clec5a is critical for dengue-virus-induced lethal disease. Nature 2008, 453, 672-676.

44. Platt, F.M.; Reinkensmeier, G.; Dwek, R.A.; Butters, T.D. Extensive glycosphingolipid depletion in the liver and lymphoid organs of mice treated with n-butyldeoxynojirimycin. J. Biol. Chem. 1997, 272, 19365-19372.

(C) 2015 by the authors; licensee MDPI, Basel, Switzerland. This article is an open access article distributed under the terms and conditions of the Creative Commons Attribution license (http://creativecommons.org/licenses/by/4.0/). 